\title{
Development and evaluation of a one-step real-time reverse transcription polymerase chain reaction assay for the detection of salmonid alphaviruses in serum and tissues
}

\author{
D. A. Graham ${ }^{1, *}$, C. Taylor $^{2}$, D. Rodgers $^{1}$, J. Weston $^{2}$, M. Khalili ${ }^{3}$, N. Ball $^{1}$, \\ K. E. Christie ${ }^{4}$, D. Todd ${ }^{1}$ \\ ${ }^{1}$ Department of Agriculture and Rural Development, Veterinary Sciences Division, Stoney Road, Stormont, Belfast BT4 3SD, UK \\ ${ }^{2}$ Department of Veterinary Sciences, The Queen's University of Belfast, Stoney Road, Stormont, Belfast BT4 3SD, UK \\ ${ }^{3}$ Department of Pathobiology, Faculty of Veterinary Medicine, Shahid Bahonar University, 22 Bahman Boulevard, \\ Kerman 76169-133, Iran \\ ${ }^{4}$ Intervet Norbio, Thormohlensgt. 55, 5008 Bergen, Norway
}

\begin{abstract}
We designed 4 primer pairs to amplify conserved regions of the E1 or nsP4 genes of salmonid alphavirus (SAV) and evaluated their performance in optimized 1-step SYBR green realtime RT-PCR (RRT-PCR) assays. A single primer pair, amplifying a $227 \mathrm{bp}$ segment of E1 was then chosen for further study. This RRT-PCR was shown to be highly repeatable and reproducible over a wide range of RNA dilutions, with a linear relationship between cycle threshold (Ct) value and RNA concentration over a $10^{7}$ dilution range. The limit of detection was calculated to be $\leq 1.5 \mathrm{TCID}_{50} \mathrm{ml}^{-1}$. When applied to sera previously screened by virus isolation for SAV viraemia, the RRT-PCR correctly identified all 13 culture-positive samples, as well as finding an additional 28 sera positive. Relative semi-quantitation of sera showed a very highly significant relationship between copy number and $\mathrm{TCID}_{50}\left(\mathrm{p}<0.001, \mathrm{R}^{2}=0.9563\right)$. Following experimental infection of salmon, heart samples were consistently positive until $21 \mathrm{~d}$ post infection (dpi), with (weak) positive signals still detectable in $50 \%$ of fish 70 dpi.
\end{abstract}

KEY WORDS: Real-time RT-PCR $\cdot$ SYBR green $\cdot$ Salmonid alphavirus $\cdot$ Serum $\cdot$ Heart $\cdot$ Diagnosis Resale or republication not permitted without written consent of the publisher

\section{INTRODUCTION}

The viral aetiology of pancreas disease (PD) in Atlantic salmon Salmo salar L. and sleeping disease (SD) in rainbow trout Oncorhynchus mykiss is now well recognised (Nelson et al. 1995, McLoughlin et al. 1996, Castric et al. 1997). The causative agents of these 2 conditions were initially termed salmon pancreas disease (SPDV) and sleeping disease virus (SDV) respectively. Both of these viruses are now recognised as being closely related alphaviruses for which the name salmonid alphavirus (SAV) has been proposed (Weston et al. 2002). Recent sequence analysis of multiple gene segments from a range of SAVs has indicated that strains can be assigned to 3 distinct subgroups, which tend to cluster geographically and by species of origin (Hodneland et al. 2005, Weston et al. 2005).

SAV infections can have a significant economic impact, with mortalities in some outbreaks in salmon exceeding $50 \%$ (Crockford et al. 1999, McLoughlin et al. 2003). Infection in salmon and trout is characterized by progressive lesions of pancreatic atrophy, followed by multifocal cardiomyocytic necrosis, particularly affecting the compact layer, and finally by skeletal muscle myopathy affecting both red and white muscle fibres (McLoughlin et al. 2002).

Diagnosis of PD and SD has traditionally been based on clinical observations combined with typical histopathological findings, reflecting the absence of alternative diagnostic methodologies. Recently, a practical and 
rapid serological assay detecting the presence of virus neutralizing antibodies has been described (Graham et al. 2003). This assay, coupled with the recognition that SAV-infected fish undergo a viraemic phase that may be conveniently and rapidly detected in cell cultures by immunostaining (Jewhurst et al. 2004) provided a novel diagnostic approach to detect and follow the progress of SAV infections in farm and experimental situations (Graham et al. 2005). RT-PCR represents an alternative rapid diagnostic approach that has not been widely used for SAV detection. To date, sequence information for primer design has been available from only a very limited number of isolates, raising concerns about the ability of primers deduced from this limited data to accurately detect all SAV strains and subtypes. As part of a recent EU-funded project (Diagnoses, Pathogeneses and Epidemiologies of Salmonid Alphavirus Diseases; QRLK2CT-2001-00970) our laboratory (Veterinary Sciences Division, Belfast) has produced more than 100 additional isolates from serum and tissue. Recent analysis of sequence data from 2 gene segments of some of these strains, as well as from strains supplied by other members of the project consortium has provided the opportunity to identify new potential primer pairs recognizing conserved sequences from geographically and temporally diverse SAV isolates from salmon and trout.

Real-time RT-PCR (RRT-PCR) protocols have been described in recent years for the detection of viral pathogens of a wide range of species and from many different sample types (Oleksiewicz et al. 2001, Letellier \& Kerkhofs 2003, Gibellini et al. 2004, Munir \& Kibenge 2004, Richards et al. 2004, van Rijn et al. 2004). This approach offers a rapid result without the need for post-amplification handling of amplicons, and therefore has an associated decreased risk of cross contamination. In addition, these protocols may also be used semi-quantitatively or quantitatively to measure virus load (Oleksiewicz et al. 2001, Gibellini et al. 2004, Richards et al. 2004). RRT-PCR protocols use a variety of chemistries to detect a signal, including sequence-specific fluorogenic probes or the incorporation of intercalating dyes such as SYBR green, followed by first derivative melt curve analysis (Niesters 2001).

The present paper describes the comparative evaluation of 4 primer pairs in SYBR green RRT-PCR assays for the detection of SAV in serum and heart tissue.

\section{MATERIALS AND METHODS}

Primer selection. We evaluated 4 different primer pairs. Two of these pairs, designated 332 and 286, amplify 332 and 286 bp sequences of the nsP4 and E1 genes of SAV respectively (Table 1). These 2 primer pairs were designed previously in our laboratory based on alignments of sequence data from the reference SPDV and SDV strains (F93-125 and S49p respectively) and 3 recent UK isolates, 1 from salmon and 2 from trout. These 2 primer pairs were then used to generate sequence data for a diverse range of 13 additional SAVs from both salmon and trout of Irish, English, Scottish, Norwegian and French origin (Weston et al. 2005). These 18 partial nsP4 (290 nucleotides, nt) and E1 (245 nt) sequences were aligned using CLUSTAL within the PHYLIP package (Department of Genetics, University of Washington) and analysed to identify additional primer pairs more suitable for realtime assays. Further details of these viruses and the accession numbers of the sequence data are provided by Weston et al. (2005). Preferred criteria for primer selection were as follows: similar melting temperatures $\left(T_{\mathrm{m}}\right)$ for pairs of primers and ideally in the range $58-60^{\circ} \mathrm{C}$; GC content of $30-80 \%$; amplified product of 50-150 bp; no more than 3 identical nucleotides sequentially; and no more than $2 \mathrm{G} / \mathrm{C}$ bases in the last 5 nucleotides at the 3 ' end.

Virus growth and titration. A pool of the reference salmon strain of SAV, F93-125 at 18th passage was inoculated onto chinook salmon embryo cells (CHSE214) and harvested $7 \mathrm{~d}$ later. This virus pool (SPDV 19) was aliquoted and stored at $-80^{\circ} \mathrm{C}$ for subsequent use. To determine the titre of the virus pool, $50 \mu \mathrm{l}$ volumes of serial 10-fold dilutions were inoculated onto CHSE214 cells in a microtitre plate and viral growth was

Table 1. Primer details. The genome segment is relative to $5^{\prime}$-terminus of F93-125. $T_{\mathrm{m}}$ : melting temperature; nt: nucleotides

\begin{tabular}{|c|c|c|c|c|}
\hline Primer pair & Sequence & GC (\%) & $T_{\mathrm{m}}\left({ }^{\circ} \mathrm{C}\right)$ & Genome segment (nt) \\
\hline 332-F (21-mer) & 5'-GTGATGCACAGCAGAGTCGAA-3' & 52.4 & $61.0^{\circ} \mathrm{C}$ & \multirow[t]{2}{*}{$6802-7133$ (nsP4) } \\
\hline $332-\mathrm{R}(21$-mer $)$ & 5'-TCGAATGAGGAGATGTCCGTT-3' & 47.6 & $60.4^{\circ} \mathrm{C}$ & \\
\hline 137-F (17-mer) & 5'-TCGGAGGTGGCTATGGA-3' & 58.8 & $56.9^{\circ} \mathrm{C}$ & \multirow[t]{2}{*}{$6842-6978(\mathrm{nsP} 4)$} \\
\hline 137-R (17-mer) & 5'-CACAAGTACGCGGTGGC-3' & 64.7 & $58.1^{\circ} \mathrm{C}$ & \\
\hline 286-F (20-mer) & 5'-ATCGGCGAAGAGGTCTATAA-3' & 45 & $55.1^{\circ} \mathrm{C}$ & \multirow[t]{2}{*}{$11020-11307$ (E1) } \\
\hline 286-R (21-mer) & 5'-CACAATCGAGGGCCAGGAGCG-3' & 66.7 & $70.0^{\circ} \mathrm{C}$ & \\
\hline 227-F (20-mer) & 5'-GACTGGCCTCCTTACGGGG-3' & 68.4 & $62.6^{\circ} \mathrm{C}$ & \multirow[t]{2}{*}{$11045-11271$ (E1) } \\
\hline 227-R (21-mer) & 5'-TTACAACCGTGCGGTGCTGT-3' & 55 & $63.3^{\circ} \mathrm{C}$ & \\
\hline
\end{tabular}


measured after $7 \mathrm{~d}$ using a monoclonal antibody-based immunoperoxidase technique (Graham et al. 2003). The titre of the virus was then calculated according to the method of Karber (1931).

RNA extraction. RNA was extracted from clarified cell culture grown viruses and serum using High Pure Viral RNA kits (Roche). The kits were used according to the manufacturer's instructions to extract RNA from $200 \mu \mathrm{l}$ aliquots. A final volume of $50 \mu \mathrm{l}$ of purified RNA was eluted from each sample, representing a 4 -fold increase of the input RNA concentration. Where insufficient volumes of sera were available, an initial dilution was prepared (maximum 1/10) in diethyl pyrocarbonate (DEPC) water (Ambion) before extraction.

Total RNA was extracted from heart samples with the QIAGEN RNeasy Mini Kit (Qiagen). Prior to extraction, 15 to $30 \mathrm{mg}$ of each sample was placed in a tube with RLT lysis buffer containing $1 \% \mathrm{v} / \mathrm{v}$ $\beta$-mercaptoethanol (Lysing Matrix tube D, Qbiogene) and disrupted and homogenized using a Ribolyser (Hybaid). The volume of buffer added to each tube was adjusted to maintain a constant ratio of tissue:buffer (30 mg:600 $\mu \mathrm{l}$ ). Total RNA was then extracted from the clarified eluate according to the manufacturer's instructions, with RNA eluted in a $50 \mu \mathrm{l}$ volume.

Real-time RT-PCR. One step, closed tube RRT-PCR was performed in $25 \mu \mathrm{l}$ volume reactions using a Rotorgene RG-3000 Version 5.0 thermocycler (Corbett Research) and Quantitect SYBR green RT-PCR kits according to the manufacturer's instructions (QIAGEN). The cycle number (40) and conditions for reverse transcription $\left(50^{\circ} \mathrm{C}\right.$ for $\left.30 \mathrm{~min}\right)$, initial PCR activation $\left(95^{\circ} \mathrm{C}\right.$ for $15 \mathrm{~min})$, denaturation $\left(94^{\circ} \mathrm{C}\right.$ for $\left.30 \mathrm{~s}\right)$ and extension $\left(72^{\circ} \mathrm{C}\right.$ for $\left.30 \mathrm{~s}\right)$ were kept constant throughout. At the end of each run, a melt analysis was performed in $1^{\circ} \mathrm{C}$ increments from 65 to $95^{\circ} \mathrm{C}$. For subsequent analysis of results, Ct values were typically determined at a threshold of 0.1 using the dynamic tube normalization and noise slope correction protocols.

Optimisation and comparison of RRT-PCR protocols. For each primer pair the extension temperature and primer concentration were determined sequentially by experiment using RNA extracted from triplicate log dilutions of SPDV19. The specific temperatures evaluated for a given primer pair varied slightly, based on their determined $T_{\mathrm{m}}$, but were all in the range 51 to $59^{\circ} \mathrm{C}$. Primer concentrations were evaluated in the range 0.4 to $1.0 \mu \mathrm{M}$. All reactions were carried out in $25 \mu$ volumes comprising $12.5 \mu \mathrm{l} 2 \times$ Quantitect SYBR green RT-PCR mastermix, $0.25 \mu \mathrm{l}$ QuantiTect RT mix, $2.5 \mu$ l template, variable volumes of forward and reverse primers (all at an initial concentration of $5.0 \mu \mathrm{M}$ ) and DEPC water.

Comparative evaluation of the sensitivity of the 4 protocols was performed by testing a dilution series of
SPDV 19 from $10^{-1}$ to $10^{-6}$. Specificity was determined by testing RNA extracted from infectious pancreatic necrosis virus (IPNV), viral haemorrhagic necrosis virus (VHSV), spring viraemia of carp virus (SVCV), tench rhabdovirus (TRV), infectious haematopoietic necrosis virus (IHNV) and infectious salmon anaemia virus (ISAV) at neat and 1/10 dilutions.

Production of in vitro-transcribed RNA. A $286 \mathrm{bp}$ PCR product derived from SPDV19 was purified using the Wizard ${ }^{\circledR}$ PCR Preps DNA Purification System (Promega), cloned into the $\mathrm{pCR}^{\circledR} \mathrm{II}-\mathrm{TOPO}{ }^{\circledR}$ vector using the TOPO TA Cloning ${ }^{\circledR}$ Kit (Invitrogen), and transformed into Top10 chemically competent E. coli cells, according to the manufacturers' instructions. Ampicillin-resistant transformants were picked and grown overnight in Luria-Bertani broth containing ampicillin $\left(50 \mu \mathrm{g} \mathrm{ml}^{-1}\right)$ at $37^{\circ} \mathrm{C}$. Minipreps of clones were prepared from $5 \mathrm{ml}$ cultures using the QIAprep ${ }^{\circledR}$ Spin Miniprep Kit (QIAGEN). A $4 \mu \mathrm{l}$ aliquot of miniprep from each clone was digested with EcoR I (Sigma) and the products visualised on a $1 \%$ agarose gel to select clones containing 286 bp inserts. Two clones were sequenced using the BigDye ${ }^{\circledR}$ Terminator v3.1 Cycle Sequencing Kit (Applied Biosystems), with M13 primers, to confirm the presence of the SP6 site, the sequence of the insert, and the Xba I site. Sequence analysis was carried out using the Informax Vector NTI Advance 9 software (Invitrogen). DNA from 8 minipreps containing inserts were digested with $\mathrm{Xba} \mathrm{I}$, and $2 \mu \mathrm{l}$ of each digest visualised on an agarose gel to check for linearisation. The remainder of the digests were pooled and purified using the Wizard ${ }^{\circledR}$ DNA Clean-Up System (Promega). In vitro-transcribed RNA was then produced using the mMESSAGE mMACHINE ${ }^{\mathrm{TM}}$ Kit (Ambion), as directed by the manufacturer.

Repeatability and reproducibility. To determine repeatability (intra-assay variation), log dilutions in DEPC water of SPDV19 RNA from $10^{-1}$ to $10^{-5}$ were prepared. 5 replicates of each dilution were tested on the same run, and the mean $\mathrm{Ct}$ value, standard deviation and \% CV calculated for each dilution.

To measure reproducibility (inter-assay variation), the same dilution series was tested in duplicate on 5 different occasions and similarly analysed. In addition, data generated on 8 separate occasions when serial dilutions of in vitro-transcribed RNA were tested in triplicate were also analysed. These dilutions were prepared in RNA extracted from SAV-negative sera.

Serum samples. A total of 121 sera (Panel 1) from 11 separate farms in Ireland, the UK and Norway were tested by RRT-PCR. These included samples from salmon, rainbow trout and sea trout (Table 2). With the exception of the last 2 sample sets, the remainder came from sites where SAV-induced disease was present or suspected. These sera had been tested for the presence 
Table 2. Details of sera tested and summary of serological, virological and real-time reverse transciption PCR (RRT-PCR) results

\begin{tabular}{|c|c|c|c|c|c|}
\hline \multirow[t]{2}{*}{ Species } & \multirow[t]{2}{*}{ Country } & \multirow{2}{*}{$\mathrm{n}$} & \multicolumn{3}{|c|}{ No. positive by: } \\
\hline & & & Serology & Isolation & RRT-PCR \\
\hline Salmon & Ireland & 12 & 0 & 3 & 4 \\
\hline Salmon & Ireland & 15 & 1 & 7 & 11 \\
\hline Rainbow trout & UK & 20 & 3 & 1 & 4 \\
\hline Salmon & Ireland & 5 & 0 & 1 & 1 \\
\hline Salmon & Ireland & 5 & 0 & 1 & 1 \\
\hline Rainbow trout & Italy & 8 & 0 & 0 & 8 \\
\hline Rainbow trout & $\mathrm{UK}^{+}$ & 6 & 5 & 0 & 2 \\
\hline Sea trout & Norway & 10 & 2 & 0 & 6 \\
\hline Sea trout & Norway & 10 & 7 & 0 & 4 \\
\hline Salmon & UK & 15 & 0 & 0 & 0 \\
\hline Rainbow trout & UK & 15 & 0 & 0 & 0 \\
\hline Total & & 121 & 12 & 13 & 41 \\
\hline
\end{tabular}

of SAV viraemia and for virus-neutralizing antibodies as previously described (Jewhurst et al. 2004). In some submissions, only antibody negative sera were tested by RRT-PCR.

In addition, 10 viraemic rainbow trout sera from a farm experiencing an outbreak of SD were tested (Panel 2). The titres of these sera had previously been determined in CHSE-214 as described above. Relative semi-quantitation was performed on these samples using the Rotorgene software by comparing the $\mathrm{Ct}$ value of each sample against a standard curve constructed from the $\mathrm{Ct}$ values of triplicate analyses of in vitro-transcribed RNA in a dilution series from $10^{-2}$ to $10^{-9}$, with the lowest dilution giving a positive signal being considered to contain 1 unit.

Heart samples. Atlantic salmon $(40 \pm 5 \mathrm{~g})$ were anaesthetized and inoculated intraperitoneally with $2 \times 10^{3} \mathrm{TCID}_{50}$ of F02-143, a salmon isolate from Ireland. Additional fish in a separate tank were mock inoculated as controls. Full details of this experiment will be published elsewhere. Heart samples for RRTPCR were collected into $400 \mu \mathrm{l}$ RNAlater $^{\circledR}$ (Ambion) from 10 infected and 5 control fish at $7,14,21,35$ and $70 \mathrm{~d}$ post infection (dpi). The tissues were stored at $-80^{\circ} \mathrm{C}$ prior to testing. Each time a set of samples was run, a triplicate dilution series of in vitro-transcribed RNA was included and used to construct a standard curve as already described. Relative semiquantitative analysis of results was then performed using the Rotorgene software by comparing the $\mathrm{Ct}$ values of samples (previously normalised to a constant tissue:buffer ratio) to this curve. The values obtained for positive samples were then log-transformed and the geometric mean titre $\left(\mathrm{GMT}_{;} \log _{10}\right)$ and the associated standard deviation calculated for the RRT-PCR samples at each sample point (Thrusfield 1995).

\section{RESULTS}

\section{Selection of additional primers and optimized RRT-PCR conditions}

Based on the alignments of the partial nsP4 and E1 sequence data, it was not possible to identify primer pairs that met all of the preferred criteria. Nevertheless, 2 further primer pairs with conserved sequences in all 18 virus strains were selected for further evaluation. One primer pair, designated 137, amplified a $137 \mathrm{bp}$ region of the nsP4 gene, while the other pair (227) amplified a 227bp segment of the E1 gene (Table 1). Selected annealing temperatures for primer pairs 332, 286, 227 and 137 were $55,55,57$ and $57^{\circ} \mathrm{C}$ respectively. The volumes $(\mu \mathrm{l})$ of $5 \mu$ forward and reverse primers added to the master mix for these pairs were $2.5,4.0,3.0$ and 4.0 respectively.

\section{Comparison of optimized RT-PCR protocols}

Details of results are given in Table 3. All 4 primer pairs gave highly linear standard curves when tested against serial dilutions of SPDV 19. The standard curves generated with primer pairs 137, 227 and 332 were similar, giving a signal at $10^{-5}$ but not at $10^{-6}$. This indicates an analytical sensitivity of $\leq 1.5 \mathrm{TCID}_{50}$ per reaction. Primer pair 286 was the least sensitive, only being positive to $10^{-4}$ and having distinctly higher $\mathrm{Ct}$ values than the others at each dilution.

Using primer pairs 227 and 332, no specific signals were detected when RNA from the other non-SAV viruses were assayed. Using primer pairs 286 and 137, weak $T_{\mathrm{m}}$ peaks were detected close to the specific melting temperatures for these primers with IHNV (286) and IPNV, ISAV and TRV (137). Except in the case of ISAV (neat only), these $T_{\mathrm{m}}$ peaks were

Table 3. Details of comparative evaluation of RRT-PCR reactions using different primer pairs. Values are cycle threshold $(\mathrm{Ct})$; -: negative. SPDV: salmon pancreas disease virus (dilution in parantheses). $T_{\mathrm{m}}$ : melting temperature

\begin{tabular}{|lcccr|}
\hline & \multicolumn{4}{c|}{ Primer pair } \\
& 137 & 227 & 286 & 332 \\
\hline SPDV 19 $\left(10^{-1}\right)$ & 17.7 & 18.8 & 22.8 & 18.8 \\
SPDV 19 $\left(10^{-2}\right)$ & 21.46 & 22.0 & 25.4 & 22.6 \\
SPDV 19 $\left(10^{-3}\right)$ & 25.09 & 25.6 & 28.8 & 25.3 \\
SPDV 19 $\left(10^{-4}\right)$ & 28.2 & 28.4 & 33.6 & 29.2 \\
SPDV 19 $\left(10^{-5}\right)$ & 32.19 & 30.9 & - & 32.8 \\
SPDV 19 $\left(10^{-6}\right)$ & - & - & - & - \\
Efficiency & 0.90 & 1.11 & 0.89 & 0.94 \\
$\mathrm{R}^{2}$ & 0.9982 & 0.9951 & 0.9902 & 0.9979 \\
$T_{\mathrm{m}}\left({ }^{\circ} \mathrm{C}\right)$ & $85.4 \pm 0.1$ & $86.1 \pm 0.1$ & $85.6 \pm 0.1$ & $87.2 \pm 0.1$ \\
& & & & \\
\hline
\end{tabular}


observed with both neat and 1/10 extracts. No bands of the appropriate size were observed from these reactions when examined by gel electrophoresis.

Based on these initial results, primer pair 227 was chosen for further evaluation.

\section{Repeatability and reproducibility}

The results generated with serial dilutions of SPDV 19 indicated that the assay based on primer pair 227 was highly repeatable at a range of concentrations, with \%CV values of 1.56 to $2.96 \%$ (Table 4 ). Reproducibility was also high, with \% CV values generated with SPDV 19 ranging from 1.27 to $5.25 \%$ (Table 5). Analysis of the parallel data generated with serial dilutions in vitro-transcribed RNA also had a high level of reproducibility, ranging from 3.15 to $8.77 \%$ (Table 6 ). These results also demonstrated that the assay had a wide dynamic range,

Table 4. Repeatability data for primer pair 227 generated with SPDV 19. Ct: cycle threshold; SD: standard deviation

\begin{tabular}{|c|c|c|c|c|c|c|c|c|}
\hline \multirow[t]{2}{*}{ Dilution } & \multicolumn{5}{|c|}{ Replicates } & \multirow[t]{2}{*}{ Mean } & \multirow[t]{2}{*}{$\mathrm{SD}$} & \multirow{2}{*}{ CV $(\%)$} \\
\hline & Ct1 & Ct2 & $\mathrm{Ct} 3$ & $\mathrm{Ct} 4$ & Ct5 & & & \\
\hline $1 / 10$ & 19.99 & 20.39 & 20.7 & 20.34 & 19.93 & 20.27 & 0.32 & 1.56 \\
\hline $1 / 100$ & 23.08 & 22.96 & 22.86 & 23.66 & 22.52 & 23.02 & 0.42 & 1.81 \\
\hline $1 / 1000$ & 27.40 & 26.17 & 26.69 & 26.65 & 26.16 & 26.61 & 0.51 & 1.90 \\
\hline $1 / 10000$ & 28.26 & 29.02 & 30.31 & 28.27 & 28.56 & 28.88 & 0.85 & 2.96 \\
\hline $1 / 100000$ & 30.37 & 31.29 & 30.91 & 31.98 & 32.38 & 31.39 & 0.81 & 2.57 \\
\hline
\end{tabular}

Table 5. Reproducibility data for primer pair 227 generated with SPDV 19. SD: standard deviation

\begin{tabular}{|c|c|c|c|c|c|c|c|c|}
\hline \multirow{2}{*}{ Dilution } & & & \multicolumn{3}{|l|}{ - Run } & \multirow{2}{*}{ Mean } & \multirow[t]{2}{*}{$\mathrm{SD}$} & \multirow{2}{*}{ CV $(\%)$} \\
\hline & 1 & 2 & 3 & 4 & 5 & & & \\
\hline $1 / 10$ & 19.14 & 20.72 & 21.48 & 19.20 & 19.45 & 20.00 & 1.05 & 5.25 \\
\hline $1 / 100$ & 22.97 & 22.08 & 22.49 & 22.17 & 21.65 & 22.27 & 0.49 & 2.20 \\
\hline $1 / 1000$ & 24.24 & 25.19 & 25.41 & 26.29 & 24.40 & 25.11 & 0.83 & 3.30 \\
\hline $1 / 10000$ & 27.31 & 28.32 & 28.50 & 28.48 & 27.95 & 28.11 & 0.50 & 1.78 \\
\hline 1/100 000 & 31.02 & 31.99 & 32.00 & 31.60 & 31.74 & 31.67 & 0.40 & 1.27 \\
\hline
\end{tabular}

showing a linear relationship between $\mathrm{Ct}$ value and RNA concentration over a $10^{7}$ range $\left(R^{2}=0.9933\right.$, Fig. 1).

\section{Serum samples}

Of the 121 sera tested, 13 sera from 5 submissions had been found SAV-positive by virus isolation (Table 2). All of these sera were also found to be positive by RRT-PCR. In addition, a further 28 sera were positive by RRT-PCR, including 4 from rainbow trout, sea trout and salmon where SD or PD was suspected clinically. The $\mathrm{Ct}$ values of the sera from which virus had been isolated ranged from 11.6 to 22.8, whereas the values for sera positive only by RRT-PCR ranged from 23.7 to 32.2). Further analysis of these values was not possible, since some samples had been diluted in DEPC water prior to testing. Of the 41 positive RRTPCR results 35 came from seronegative fish.

Some of the sera that tested positive gave an atypical amplification profile, characterized at its most extreme by a linear rather than a sigmoid relationship between fluorescent intensity and $\mathrm{Ct}$ value. This type of profile appeared to be associated with haemolysed sera. The majority of these samples gave a typical profile when the RNA was diluted $1 / 10$ and re-tested, and in all cases when diluted 1/100 (Fig. 2). Atypical profiles were also seen with some negative sera. Positive and negative sera could always be distinguished by $T_{\mathrm{m}}$ analysis, irrespective of their amplification profile.

Viral titres of the Panel 2 sera ranged from $10^{3.25}$ to $10^{8.0} \mathrm{TCID}_{50}$ $50 \mathrm{\mu l}^{-1}$. A strong linear relationship $\left(\mathrm{R}^{2}\right.$ $=0.9563, \mathrm{p}<0.001)$ was demonstrated between viral titre and genome copy number (Fig. 3).

Table 6. Reproducibility data for primer pair 227 generated with in vitro-transcribed RNA. Ct: cycle threshold; SD: standard deviation

\begin{tabular}{|c|c|c|c|c|c|c|c|c|c|c|c|}
\hline \multirow{2}{*}{ Dilution } & & & & \multicolumn{5}{|c|}{ Run (Ct values) } & \multirow[t]{2}{*}{ Mean } & \multirow[t]{2}{*}{$\mathrm{SD}$} & \multirow[t]{2}{*}{$\mathrm{CV}(\%)$} \\
\hline & 1 & 2 & 3 & 4 & 5 & 6 & 7 & 8 & & & \\
\hline $10^{-2}$ & 5.56 & 5.50 & 5.62 & 5.92 & 5.56 & 6.59 & 6.07 & 6.83 & 5.96 & 0.49 & 8.23 \\
\hline $10^{-3}$ & 8.06 & 8.02 & 8.01 & 8.34 & 8.11 & 9.79 & 8.94 & 9.86 & 8.64 & 0.76 & 8.77 \\
\hline $10^{-4}$ & 11.10 & 11.08 & 11.01 & 11.32 & 11.24 & 13.05 & 12.17 & 13.33 & 11.79 & 0.90 & 7.66 \\
\hline $10^{-5}$ & 14.61 & 14.54 & 14.57 & 14.88 & 14.61 & 16.54 & 15.67 & 16.77 & 15.27 & 0.90 & 5.88 \\
\hline $10^{-6}$ & 17.77 & 17.66 & 17.67 & 18.07 & 17.83 & 19.66 & 18.96 & 19.66 & 18.41 & 0.87 & 4.71 \\
\hline $10^{-7}$ & 21.09 & 21.06 & 21.14 & 21.49 & 21.20 & 22.54 & 22.36 & 23.11 & 21.75 & 0.79 & 3.63 \\
\hline $10^{-8}$ & 23.98 & 23.77 & 24.05 & 24.14 & 23.92 & 23.49 & 24.81 & 26.04 & 24.28 & 0.76 & 3.15 \\
\hline $10^{-9}$ & 25.53 & 24.66 & 25.49 & 26.13 & 25.29 & 23.56 & 25.36 & 27.61 & 25.45 & 1.10 & 4.30 \\
\hline
\end{tabular}




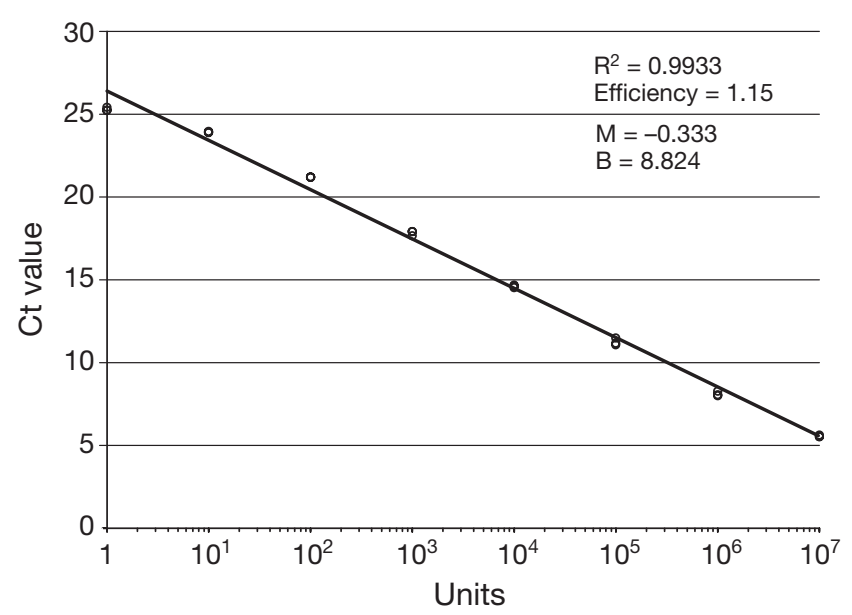

Fig. 1. Standard curve generated from Ct values ( $y$-axis) of triplicate serial 10-fold dilutions of in vitro-transcribed RNA with primer pair 227. M: slope; B: $X$-axis intercept

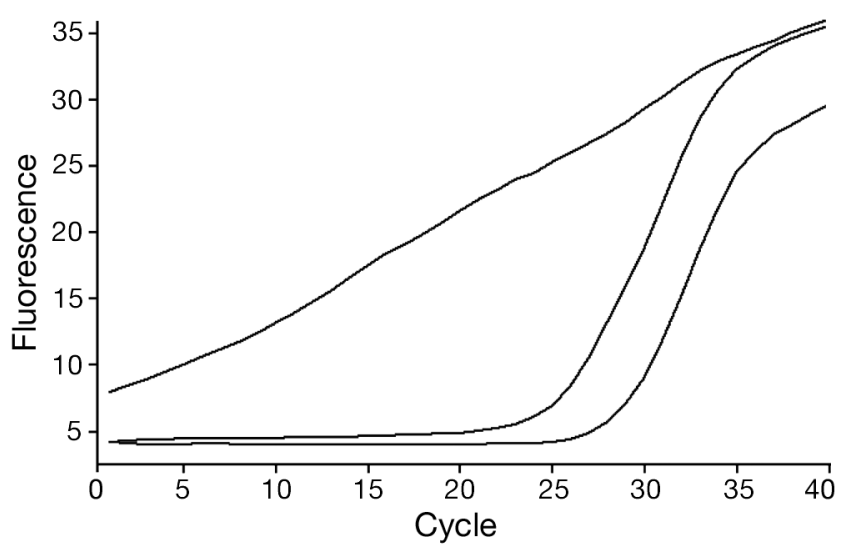

Fig. 2. RRT-PCR curves for undiluted, 1/10 and 1/100 dilutions (left to right) of RNA extracted from a positive serum

\section{Heart samples}

A positive RRT-PCR signal was detected in all hearts collected from infected fish at 7,14 and 21 dpi (Table 7). At 35 and 70 dpi the number of positive samples decreased to $90 \%$ then to $50 \%$. Analysis of relative semi-quantitative results indicated that copy numbers varied approximately $10^{4}$-fold over the sampling period (Table 7). Peak geometric mean titres were observed at $14 \mathrm{dpi}$, with a decline thereafter that was especially marked between 21 and 35 dpi. No positive results were obtained with the control samples, and no atypical signals were observed.

\section{DISCUSSION}

The results presented here demonstrate that primer pair 227 can form the basis of a highly sensitive and specific 1-step RRT-PCR for both serum and tissue samples that is both highly repeatable and reproducible. Initial studies with SPDV 19 RNA and subsequently with in vitro-transcribed RNA showed that the reaction had a wide dynamic range with linear responses over a $10^{7}$-fold concentration range.

Although primer pairs 227 and 332 showed the same analytical sensitivity on initial evaluation, 227 was only chosen over 332 because of the smaller product size. It is generally recommended that RRT-PCR reactions should be designed to amplify products of 50 to $150 \mathrm{bp}$. Nevertheless, the results presented here show that primer pairs for larger products can be used successfully in real-time reactions for SAV. The cause of the weak non-specific signals shown by primer pairs 137 and 286 with some viruses when melt curve analysis was performed is unknown. A BLAST search failed to identify any significant homology between these primer sequences and these viruses. While the presence of these signals may preclude use of these primers for routine diagnostic work, they are still useful for research applications such as generation of sequence data or cell culture studies. The lower sensitivity of primer pair 286 is considered to be a reflection of the discrepancy in $T_{\mathrm{m}}$ between forward and reverse primers. Although the data presented here relate to RRT-PCR, these primer pairs have all been shown to have equivalent sensitivities in conventional RT-PCR, except for 332, which showed a 10-fold decrease in sensitivity (authors' unpubl. data).

Serum has recently been shown to be a convenient sample from which to isolate SAV (Graham et al. 2003, Jewhurst et al. 2004). This approach, which requires minimal processing of samples following their receipt in the laboratory, is particularly suited to individual screening of large numbers of samples that can also be screened for SAV-neutralizing antibodies at the same time (Jewhurst et al. 2004). Additionally, virus can be detected after only $3 \mathrm{~d}$, as opposed to conventional methods based on serial passage of pooled tissues, which can take several weeks to yield an isolate (Nelson et al. 1995). It also has the further advantage of offering non-destructive testing where required. In our hands, this approach has enabled us to make more than 100 isolates from salmon and trout since 2002 (D. A. Graham unpubl. data). The results obtained with the Panel 1 sera show that RRT-PCR is a much more sensitive test than screening for viraemia after $3 \mathrm{~d}$, as indicated by the detection of specific signals in 28 culture-negative samples. In 4 of these cases (Table 2), no viruses were isolated. The fact that all of these were clinically suspect cases of PD or SD, and seropositive fish were present in 3 sets, suggests that the RRT-PCR results are genuine. The sensitivity of the culture method is limited by the short incubation time and the small input volume of serum. The higher $\mathrm{Ct}$ values 


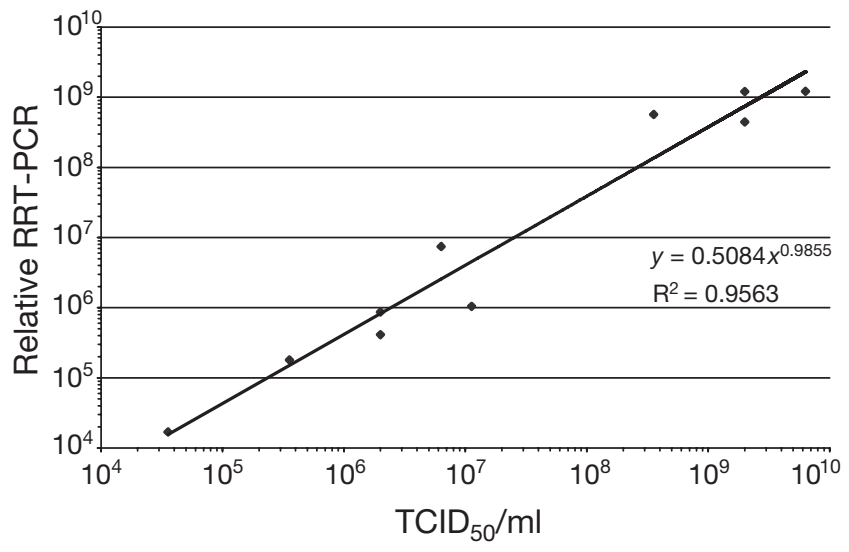

Fig. 3. Correlation between virus load in serum samples as determined by titration in cell culture and by RRT-PCR

associated with the culture-negative/RRT-PCR-positive samples suggests that the viral load in these samples may have been below the detection limit of the culture method as applied to these samples. Loss of virus viability (particularly during transport), while retaining sufficient RNA to give a positive RRT-PCR signal, is another possible explanation for these results. The observation that almost all of the RRT-PCR sera came from seronegative fish suggests that the development of a specific humoral immune response is associated with viral clearance from serum. This is consistent with the findings from experimental infections (D. A. Graham \& R. E. Christie unpubl. data), with a seropositive but virus-negative results from a population being considered indicative of previous infection. The successful amplification of RRT-PCR product from viruses from salmon and trout from several countries (including the first positive result from Italy) indicates the broad reactivity of primer pair 227 with SAV strains, consistent with the initial design aim.

Determining virus load in serum or tissues by endpoint titration in cell culture is labour intensive, and the quantitative use of RRT-PCR, based on the linear relationship between $\mathrm{Ct}$ value and RNA concentration offers a potential alternative. However, a range of factors, including quality and quantity of input RNA, nonuniformity of tissues, efficiencies of RNA extraction, reverse-transcription and $\mathrm{PCR}$, and the presence of inhibitors may all influence the $\mathrm{Ct}$ value obtained for a

Table 7. Salmo salar. Geometric mean titres $\left(\log _{10}\right) \pm$ standard deviation of RRT-PCR results for heart samples. dpi: days post-infection

\begin{tabular}{|lcccccc|}
\hline & 7 & \multicolumn{6}{c}{ dpi } \\
\cline { 2 - 6 } & 7 & 14 & 21 & 35 & 70 \\
\hline $\begin{array}{l}\text { \% positive } \\
\text { Relative } \\
\text { copy number }\end{array}$ & $2.88 \pm 0.77$ & $3.84 \pm 0.63$ & $3.62 \pm 0.55$ & $0.48 \pm 0.28$ & $0.15 \pm 0.16$ \\
\hline
\end{tabular}

given sample (Vandesompele et al. 2002, Huggett et al. 2005). These factors are considered to have the greatest influence in non-homogenous samples containing high levels of total RNA (Oleksiewicz et al. 2001). A number of different strategies have been proposed to normalize quantitative RRT-PCR values, including use of fixed sample volume/ weight, reference ribosomal or messenger RNAs, total RNA and alien molecules (Huggett et al. 2005). For semi-quantitative analysis of Panel 2 sera, normalization was restricted to having the same input volume for each sample. Despite this simple approach, the results indicated a very highly significant relationship between TCID $_{50}$ and RRT-PCR values. This approach is consistent with that used by others (Gibellini et al. 2004) and the good correlation is at least partly attributable to the fixed starting volume, homogeneity of the sample and the low levels of total RNA found in serum (Oleksiewicz et al. 2001). Nevertheless, the observation of atypical profiles with some Panel 1 sera indicates the potential for inaccuracy with this approach, and in subsequent unrelated studies (D. A. Graham unpubl. data) $\beta$ actin mRNA has also been quantified and used to normalize SAV values (Pfaffl et al. 2002). The association between haemolysed samples and atypical profiles highlights the need for care to be taken when collecting and separating blood samples.

The choice of SYBR green as opposed to fluorogenic probes as the detection method in these assays was based on a number of factors. These assays are simpler to standardize and cheaper to run and, in addition, are less prone to give false negative results with variant viruses, due to sequence divergence. The use of a large panel of viruses for primer selection was designed to further guard against this. However, the use of fluorogenic probes would have resolved the problems of atypical profiles and weak non-specific signals seen with SYBR green, as well as possibly improving the overall sensitivity of the assay. Our intention is to explore the use of alternative detection methods with these primers in future work.

Normalisation of RRT-PCR results from heart samples was restricted to using a constant w/v ratio during RNA extraction. The results presented are therefore semi-quantitative only. Nevertheless, they clearly show that SAV can be detected by RRTPCR from heart for a considerable period after infection, and that the viral load present in positive sample changes with time. Serum virus-neutralizing antibodies are first detectable from 10 to 21 dpi (McLoughlin 1999), and the marked drop in relative copy number between 21 and $35 \mathrm{dpi}$ is considered to reflect the clearance of virus 
associated with this response. Further work is necessary to determine whether these low level positive signals indicate genuine viral persistence with low levels of virus replication or represent merely the continued presence of viral RNA.

In conclusion, a sensitive, specific quantitative RRTPCR based on amplification of a $227 \mathrm{bp}$ fragment of the E1 gene has been developed and shown to be suitable for testing both serum and heart tissue. The sensitivity of this methodology provides the means to address currently unanswered questions in relation to the epidemiology and pathogenesis of SAV infections, in addition to its use as a routine diagnostic assay.

Acknowledgements. This work was partly funded by EU project QLK2-CT-2001-000970 (Diagnoses, Pathogeneses and Epidemiologies of Salmonid Alphavirus Diseases) and by a grant to M. Khalili from the Ministry of Science, Research and Technology of Iran.

\section{LITERATURE CITED}

Castric J, Baudin Laurencin F, Brémont M, Jeffroy J, Le Ven A, Béarzotti M (1997) Isolation of the virus responsible for sleeping disease in experimentally infected rainbow trout (Oncorhynchus mykiss). Bull Eur Assoc Fish Pathol 17:27-30

Crockford T, Menzies FD, McLoughlin MF, Wheatley SB, Goodall EA (1999) Aspects of the epizootiology of pancreas disease in farmed Atlantic salmon Salmo salar in Ireland. Dis Aquat Org 36:113-119

Gibellini D, Vitone F, Gori E, La Placa M, Re MC (2004) Quantitative detection of human immunodeficiency virus type 1 (HIV-1) viral load by SYBR green real-time RT-PCR technique in HIV-1 seropositive patients. J Virol Methods 115: 183-189

Graham DA, Jewhurst VA, Rowley HM, McLoughlin M, Todd D (2003) A rapid immunoperoxidase-based virus neutralization assay for salmonid alphavirus. J Fish Dis 26: 407-413

Graham DA, Jewhurst VA, Rowley HM, McLoughlin MF, Rodger H, Todd D (2005) Longitudinal serological surveys of Atlantic salmon (Salmo Salar L.) using a rapid immunoperoxidase-based neutralization assay for salmonid alphavirus. J Fish Dis 28:373-379

Hodneland K, Bratland A, Christie KE, Endresen, Nylund A (2005) New subtype of salmonid alphavirus (SAV), Togaviridae, from Atlantic salmon Salmo salar and rainbow trout Oncorhynchus mykiss in Norway. Dis Aquat Org 66:113-120

Huggett J, Dheda K, Bustin S, A Zumla (2005) Real-time RTPCR normalisation; strategies and considerations. Genes Immun 1-6

Jewhurst VA, Todd D, Rowley HM, Walker IW, Weston JH, McLoughlin MF, Graham DA (2004) Detection and antigenic characterization of salmonid alphavirus isolates from sera obtained from farmed Atlantic salmon, Salmo salar L., and farmed rainbow trout, Oncorhynchus mykiss (Walbaum). J Fish Dis 27:143-149

Karber G (1931) Beitrag zur kollektiven Behandlung phar- makologischer Reihenversuche. Arch Exp Pathol Pharmakol 162:480-483

Letellier C, Kerkhofs P (2003) Real-time PCR for simultaneous detection and genotyping of bovine viral diarrhea virus. J Virol Methods 114:21-27

McLoughlin MF (1999) A study of pancreas disease in farmed Atlantic salmon. PhD dissertation, Queen's University Belfast

McLoughlin MF, Nelson RT, Rowley HM, Cox DI, Grant AN (1996) Experimental pancreas disease in Atlantic salmon Salmo salar post-smolts induced by salmon pancreas disease virus (SPDV). Dis Aquat Org 26:117-124

McLoughlin MF, Nelson RT, McCormick JI, Rowley HM, Bryson, DB (2002) Clinical and histopathological features of naturally occurring pancreas disease in farmed Atlantic salmon, Salmo salar L. J Fish Dis 25:33-43

McLoughlin MF, Peeler E, Foyle KL, Rodger HD, O'Ceallachain D, Geoghegan F (2003) An epidemiological investigation of the re-emergence of pancreas disease in Irish farmed Atlantic salmon (Salmo salar L.) in 2002. Marine Environment and Health Series, No. 14. Marine Institute, Galway

Munir K, Kibenge FSB (2004) Detection of infectious salmon anaemia virus by real-time RT-PCR. J Virol Methods 117: $37-47$

Nelson RT, McLoughlin MF, Rowley HM, Platten MA, McCormick JI (1995) Isolation of a toga-like virus from farmed Atlantic salmon Salmo salar with pancreas disease. Dis Aquat Org 22:25-32

Niesters HGM (2001) Quantification of viral load using realtime amplification techniques. Methods 25:419-429

Oleksiewicz MB, Donaldson AI, Alexandersen S (2001) Development of a novel real-time RT-PCR assay for quantitation of foot-and-mouth disease virus in diverse porcine tissues. J Virol Methods 92:23-35

Pfaffl MW, Graham W, Horgan, Dempfle L (2002). Relative expression software tool $\left(\mathrm{REST}^{\odot}\right)$ for group-wise comparison and statistical analysis of relative expression results in real-time PCR. Nucleic Acids Res 30:(9)e36

Richards GP, Watson MA, Kingsley DH (2004) A SYBR green, real-time RT-PCR method to detect and quantitate Norwalk virus in stools. J Virol Methods 116: $63-70$

Thrusfield M (1995) Veterinary epidemiology, 2nd edn. Blackwell Science, Oxford

Vandesompele J, De Preter K, Pattyn F, Poppe B, Van Roy N, De Paepe A, Speleman F (2002) Accurate normalization of real-time quantitative RT-PCR data by geometric averaging of multiple internal control genes. Genome Biol 3(7): 0034.1-0034.11

Van Rijn PA, Wellenberg GJ, van der Honing RH, Jacobs L, Moonen PLJM, Feitsma H (2004) Detection of economically important viruses in boar semen by quantitative RealTime $\mathrm{PCR}^{\mathrm{TM}}$ technology. J Virol Methods 120: 151-160

Weston J, Villoing S, Brémont M, Castric J and 7 others (2002) Comparison of two aquatic alphaviruses, salmon pancreas disease virus and sleeping disease virus, by using genome sequence analysis, monoclonal reactivity, and cross-infection. J Virol 76:6155-6163

Weston JH, Graham DA, Branson E, Rowley HM, Walker IW, Jewhurst VA, Jewhurst HL, Todd D (2005) Nucleotide sequence variation in salmonid alphaviruses from outbreaks of salmon pancreas disease and sleeping disease. Dis Aquat Org 66:105-111

Submitted: September 19, 2005; Accepted: December 20, 2005 Proofs received from author(s): March 24, 2006 